\title{
STUDY OF T-LYMPHOCYTES SUBSETS IN PATIENTS WITH HBV CHRONIC CARRIERS
}

\author{
"Ayaid K. Zqair, " Dhuha S. Salih, *A.Z.K. Muhammad, *Ghadah, M.S. and \\ Ramzia Al-Kayat \\ *Baghdad University, College of Science, Dept- of Biology. \\ ** Central Public Health LAB.
}

\begin{abstract}
This study included 13 patients with Chronic Hepatitis B (CHB), 9 individuals were diagnosed with Healthy carriers $(\mathrm{HBV}-\mathrm{HC})$ and 7 patients with autoimmune chronic active hepatitis (AICAH), and 16 human as control group. The number and the percentage of TLymphocyte $\left(\mathrm{CD}^{+}\right.$Cells) in the peripheral blood of these groups of patients showed no significant differences but in the patients with $\mathrm{CHB}$ showed reduction in the percentages and absolute numbers of $\mathrm{CD}^{+}$cells $(\mathrm{P}<0.001)$, significant decreased $\mathrm{CD} 4^{+} / \mathrm{CD} 8^{+}$cells ratio $(\mathrm{P}<$ $0.001)$ and increase in the percentages and absolute number of $\mathrm{CD}^{+}$cells $(\mathrm{P}<0.001)$ were found, in compared with healthy control group. HBV-HC group showed no significant difference in all these values. The patients with AICAH demonstrated a slight significant increase in $\mathrm{CD}^{+} /$ $\mathrm{CD} 8^{+}$cell ratio $(\mathrm{P}<0.05)$ but the percentage and absolute number of $\mathrm{CD} 8^{+}$and $\mathrm{CD} 4^{+}$cells were normal in AICAH when compared their results with control group.
\end{abstract}

\section{Introduction}

About $10 \%$ of patients suffering from acute type $\mathrm{B}$ hepatitis fail to clearance Hepatitis B Surface antigen (HBs Ag) from the blood and become chronic carriers in adult. But this percentage is $90 \%$ in children $(1,2)$. The virus is not cytotoxic for hepatocytes and the liver cells damage is related to immunological reactions patterns of host $(3,4)$. The cell mediated immune response to antigens compounds of the virus. Plays an important role in the lysis of infected hepatocytes in acute and chronic HBV Induce hepatitis (5). The expression of $\mathrm{HBV}$ surface antigen ( $\mathrm{HBs} \mathrm{Ag}$ ) or core antigen $(\mathrm{HBc} \mathrm{Ag})$ on the surface membrane of liver cells play as the main target antigens for host defense mechanisms $(6,7)$. In the patients with autoimmune chronic active hepatitis (AICAH) the immune response occur against self antigen of hepatocytes membrane, the immunopathogenic mechanisms of cellular that result in viral persistence and hepatocellular injury in type B hepatitis remained unclear $(8,9)$. Defect in the immunoregulatory system have played a role in the development of chronic hepatitis B. The importance of balance between inducer $\left(\mathrm{CD}^{+}{ }^{+}\right.$cells) and suppressor $\left(\mathrm{CD} 8^{+}\right.$ cells) cells in maintaining immune hemost- asis has recently been illustrated and abnormalities of these cells subpopulations have been associated with a number of human disease (6). Previous studies support the hypothesis: that two factors are important in pathogenesis of HBV induced hepatocellular injury ; Viral replication and immune response (10) On the strength of those investigators, the aim of this study was proposed for determination of $\mathrm{CD}^{+}$ cells and the ratio of $\mathrm{CD} 4^{+} / \mathrm{CD}^{+}$cells in blood circulation which gave a good picture for immune hemostasis .

\section{Materials \& Methods}

Patients: Twenty nine patients have previous infection with HBV. According to clinical serological and Biochemical tests. All cases were taken from Central public Health Laboratories. Forty five cases divided into following groups: CHB with clinical disorder symptoms (13), HBV - HC (9), AICAH with HBV markers (7) control group (16). Clinical and laboratory features of patients, and control groups show in table (-1-). Heparinized blood and serum was collected from all these patients and control. All cases have not any markers for other viruses except HBV markers; nobody had received immunosuppressive or antiviral drug treatment. 


\section{Methods}

1. Cells isolation: Lymphocytes were isolated from heperinized peripheral blood by density gradient centrifugation by used lymphoprepe (flow laboratory) (11). And washed three times in HBSS (flow laboratory).

2. Preparation of cell smear: $10 \mu 1$ from cells suspension $\left(10^{6}\right.$ cells $\left./ \mathrm{ml}\right)$ was smeared on clean glass slide and the last was air dried and fixed with buffer formal acetone (prepared immediately before use by mixing $8 \mathrm{ml}$ of phosphate buffer, 38 $\mathrm{ml} \mathrm{D.W}, 33.2 \mathrm{ml}$ of $40 \%$ formalin and 60 $\mathrm{ml}$ of acetone) for 30 second and the slide rinsed with D.W and transferred to Tris buffer saline (TBS,Fluka) and then dried it (12).

3. Indirect immunoperoxidase staining procedure (13) and it had modified by (12):

The slides were submerged in methanol supplemented with $0.6 \%$ of $\mathrm{H}_{2} \mathrm{O}_{2}$ (Fluka) for 15 minutes and they were rinsed in D.Wand transferred to PBS after incubated at $37{ }^{\circ} \mathrm{C}$ for 60 minutes with $50 \mu 1$ of primary monoclonal antibodies diluted to 1:600 (CD $3^{+}$or $\mathrm{CD} 4^{+}$or $\mathrm{CD} 8^{+}$markers) (these markers were prepared in mice by Biokit company) in humid chamber and washed three times with TBS carefully after that Slides were incubated at $37{ }^{\circ} \mathrm{C}$ for 60 minutes with $50 \mu$ l of peroxides conjugate (Anti-mice Immunoglobulin) (Biokit) diluted with PBS up to 1:400, the slides were washed with TBS three times, after that $50 \mu \mathrm{l}$ of 3,3 Diaminobenzide tetrahedrochlorid (Sigma) the last solution supplemented with $3 \mu \mathrm{l}$ of $\mathrm{H}_{2} \mathrm{O}_{2}$ (Fluka) incubated for 15 minutes at $37{ }^{\circ} \mathrm{C}$, the slides washed with TBS three times and placed in hematoxylin for one second and they washed with PBS and put in the same buffer for 5 minutes to develop the color and it fixed by put the slides in serial dilutions of methanol $(70 \%, 80 \%$ and 95 $\%)$ for 5 seconds in each dilutions after that Canada balsam was added and they (Slides) were covered with suitable cover slip . All slides were examined with compound microscope and the percentages were counted.

Statistical analysis: used t-test.

Table (1)

Clinical and laboratory factories of many groups of patients \& control.

\begin{tabular}{|c|c|c|c|c|c|c|c|c|}
\hline Information & \multicolumn{2}{|c|}{ CHB } & \multicolumn{2}{|c|}{ HBV-HC } & \multicolumn{2}{|c|}{ AICAH } & \multicolumn{2}{|c|}{ Control } \\
\hline \begin{tabular}{|l} 
No. patients \\
\end{tabular} & \multicolumn{2}{|c|}{13} & \multicolumn{2}{|c|}{9} & \multicolumn{2}{|c|}{7} & \multicolumn{2}{|c|}{16} \\
\hline \multirow{2}{*}{ Six } & Female & Male & Female & Male & Female & Male & Female & Male \\
\hline & 4 & 9 & 3 & $\overline{6}$ & 6 & 1 & 7 & 9 \\
\hline Rang of age in years & $20-45$ & $25-48$ & $24-38$ & $23-42$ & $22-45$ & 50 & $24-35$ & $20-40$ \\
\hline Mean of age in years & 34 & 37 & 31 & 32 & 38 & 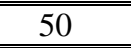 & 28 & 33 \\
\hline HBs Ag & \multicolumn{2}{|c|}{13} & \multicolumn{2}{|c|}{9} & \multicolumn{2}{|c|}{1} & \multicolumn{2}{|c|}{0} \\
\hline Anti-HBs & \multicolumn{2}{|c|}{$\overline{0}$} & \multicolumn{2}{|c|}{ 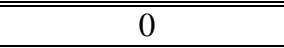 } & \multicolumn{2}{|c|}{ 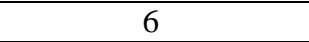 } & \multicolumn{2}{|c|}{0} \\
\hline Anti-HBc IgM & \multicolumn{2}{|c|}{$\overline{7}$} & \multicolumn{2}{|c|}{ 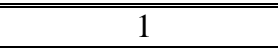 } & \multicolumn{2}{|c|}{0} & \multicolumn{2}{|c|}{ 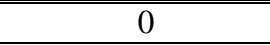 } \\
\hline Auto antibodies & \multicolumn{2}{|c|}{ 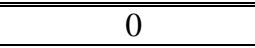 } & \multicolumn{2}{|c|}{ 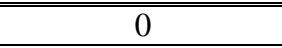 } & \multicolumn{2}{|c|}{7} & \multicolumn{2}{|c|}{0} \\
\hline ANA & \multicolumn{2}{|c|}{0} & \multicolumn{2}{|c|}{0} & \multicolumn{2}{|c|}{7} & \multicolumn{2}{|c|}{0} \\
\hline ASMA & \multicolumn{2}{|c|}{ 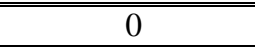 } & \multicolumn{2}{|c|}{ 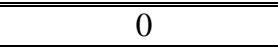 } & \multicolumn{2}{|c|}{6} & \multicolumn{2}{|c|}{ 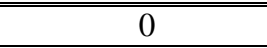 } \\
\hline $\begin{array}{l}\text { TSB } \mathrm{mg} / \mathrm{dl} \\
(0.2-1 \mathrm{mg} / \mathrm{dl}) \\
\end{array}$ & \multicolumn{2}{|c|}{$4.1 \mp 2.0$} & \multicolumn{2}{|c|}{$0.9 \mp 0.3$} & \multicolumn{2}{|c|}{$1.6 \mp 0.9$} & 0.90 & 0.12 \\
\hline ALT (2-15 Iu/L) & $\begin{array}{r}55.25 \\
(\mathrm{P}<\end{array}$ & $\begin{array}{l}31.3 \\
01)\end{array}$ & 6.6 & & $\begin{array}{l}22 \\
(\mathrm{P}\end{array}$ & & 9.3 & 5.3 \\
\hline IgG mg/dl & $\begin{array}{r}2620 \\
(\mathrm{P}\end{array}$ & $\begin{array}{l}530 \\
01)\end{array}$ & 1300 & 350 & $\begin{array}{r}2830 \\
(\mathrm{P}<\end{array}$ & $\begin{array}{l}510 \\
05)\end{array}$ & 136 & 513 \\
\hline IgM mg/dl & $\begin{array}{c}320 \\
(\mathrm{P}\end{array}$ & $\begin{array}{l}96 \\
01)\end{array}$ & 139 & & $330 \mp 9$ & $<0.005)$ & & \\
\hline IgA mg/dl & 300 & 180 & 328 & 143 & $440 \mp 21$ & $(\mathrm{P}<0.01)$ & 30 & 27 \\
\hline
\end{tabular}

NS: non significant

ALT: Alanine aminotransferase

ANA: Antinuclear antibody
TSB: Total serum bilirubine

ASMA: Anti-smooth muscle antibody

ALT: Alanine aminotransferase 


\section{Results \& Discussion}

Table-2- shows percentage and absolute numbers of $\mathrm{CD}^{+}$cells, $\mathrm{CD} 4^{+}$cells and $\mathrm{CD}^{+}$cells in many groups of patients, which have old infection with HBV. Percentages and absolute number of $\mathrm{T}$ - lymphocytes $\left(\mathrm{CD}^{+}\right.$cells) in groups of patients show no significant difference when compared with control group. Patients with CHB show more significant reduction in the percentages and absolute numbers of $\mathrm{CD} 4^{+}$ Cells (helper cells) $(\mathrm{P}<0.001)$ the same reduction were found in $\mathrm{CD}^{+} / \mathrm{CD}^{+}$cells ratio. But these patients showed a more significant increasing in percentages and absolute numbers of $\mathrm{CD} 8^{+}$Cells (Suppressor Cells) in compared with control group $(\mathrm{P}<0.001)$. Slight differences in these values were found by some investigators, $(7,14,15,16)$. It might be suggested that the imbalance of immunoregulation may be play a role in the failure of clearance HBV. The patients with HBV-HC showed no significant differences in these values when compared with control group.

Similar results were found by some investigators (15) HBV is not directly cytopathic for infected hepatocytes.
Although many studies were designed to evaluate cells mediated immunity in infected people, the immunopathogenesis of chronic hepatitis type B remains unknown but the detection of the immunoregulatory system has suggested playing a role in the developments of chronic HBV infection (16, 17). Several studies of lymphocytes subsets in liver section revealed that in acute and chronic hepatitis B,T lymphocytes are the predominant Cells in liver and $\mathrm{CD}^{+}$Cells accumulated in many areas of liver, thus they played an essential role in liver necrosis but $\mathrm{CD}^{+}$cells activity had been regulated by $\mathrm{CD} 4^{+}$cells which also present in these areas (18).

This Shows the important role which is playing by $\mathrm{CD}^{+}$cells in pathogenesity of CHB thus these cells are increasing in these patients (CHB). The immune response of $\mathrm{CD} 4^{+}$cells and $\mathrm{CD}^{+}$cells against the cells that are expressing $\mathrm{HBs} \mathrm{Ag}$ and $\mathrm{HBc} \mathrm{Ag}$ on their surfaced play an important role in HBV disappearance, thus the reduction in $\mathrm{CD}^{+} / \mathrm{CD}^{+}$cells ratio affects on presence of HBV and Cause CHB disease (19). Defective $\mathrm{CD}^{+}$cells responses to viral antigens are present in chronic HBV carriers (20).

Table (2)

Percentage and absolute numbers of $\mathrm{CD3}^{+}, \mathrm{CD4}^{+}$and $\mathrm{CD8}^{+}$cells in the study groups

\begin{tabular}{|c|c|c|c|c|c|c|c|c|}
\hline & & \multicolumn{2}{|c|}{$\mathrm{CD}_{3}$} & \multicolumn{2}{|c|}{$\mathrm{CD}_{4}$} & \multicolumn{2}{|c|}{$\mathrm{CD}_{8}$} & \multirow{2}{*}{$\begin{array}{c}\mathrm{CD}_{\mathbf{8}} / \mathrm{CD}_{\mathbf{4}} \\
\%\end{array}$} \\
\hline & & $\begin{array}{c}\mathrm{No} / \\
\approx 1100 \\
\text { cell }\end{array}$ & $\%$ & $\begin{array}{c}\text { No/ } \\
\approx 1100 \\
\text { cell }\end{array}$ & $\%$ & $\begin{array}{c}\text { No/ } \\
\approx 1100 \\
\text { cell }\end{array}$ & $\%$ & \\
\hline \multirow{2}{*}{$\begin{array}{c}\text { Control } \\
\mathrm{n}=16\end{array}$} & mean & 814.73 & 73.43 & 548.25 & 49.44 & 278.7 & 25.09 & 1.99 \\
\hline & SD & 98.9 & 6.45 & 67.8 & 4.55 & 46.4 & 32 & 0.29 \\
\hline \multirow{3}{*}{$\begin{array}{l}\text { CHB } \\
n=13\end{array}$} & mean & 788 & 70.17 & 414 & 36.95 & 369.1 & 32.798 & 1.175 \\
\hline & SD & 97.2 & 5.68 & 83.9 & 6.78 & 80.8 & 5.33 & 0.40 \\
\hline & $\begin{array}{c}\text { Diff. of } \\
\text { sign. }\end{array}$ & Ns & Ns & $\mathrm{P}<0.001$ & $\mathrm{P}<0.001$ & $\mathrm{P}<0.001$ & $\mathrm{P}<0.001$ & $\mathrm{P}<0.001$ \\
\hline \multirow{3}{*}{$\begin{array}{c}\text { HBV- } \\
\text { HC } \\
n=9\end{array}$} & Mean & 780.3 & 71.37 & 503.3 & 46.08 & 285.7 & 26.18 & 1.790 \\
\hline & SD & 60.28 & 3.47 & 38.9 & 3.29 & 39.9 & 3.05 & 0.27 \\
\hline & $\begin{array}{c}\text { Diff. of } \\
\text { sign. }\end{array}$ & Ns & Ns & Ns & Ns & Ns & Ns & Ns \\
\hline \multirow{3}{*}{$\underset{\mathbf{n}=7}{\operatorname{AICAH}}$} & Mean & 807.15 & 72.83 & 553.57 & 50.43 & 238.7 & 21.4 & 2.558 \\
\hline & SD & 68.36 & 3.76 & 48.66 & 5.1 & 64.45 & 4.6 & 0.66 \\
\hline & $\begin{array}{c}\text { Diff. of } \\
\text { sign. }\end{array}$ & Ns & Ns & Ns & Ns & Ns & Ns & $\mathrm{P}<0.05$ \\
\hline
\end{tabular}


The extraordinary variation in the course and outcome of hepatitis B may be related to modulatory factors as cytokines (21) $\mathrm{T}$ helper $1\left(\mathrm{TH}_{1}\right)$ cytokines are involved principally in cellular - mediated immunity and play a crucial role in protection from intracellular pathogen (Viruses). $\mathrm{TH}_{2}$ cytokines mostly regulate humoral immune responses which are playing a limited role in viral disappearance (22). In $\mathrm{CHB} \mathrm{TH}_{2}$ active more than $\mathrm{TH}_{1}$ thus the diseas will continue (1). In the patients with AICAH no significant differences in the percentages and absolute numbers of $\mathrm{CD}^{+}$cells, $\mathrm{CD} 4^{+}$cells and $\mathrm{CD} 8^{+}$cells were found, the reduction of $\mathrm{CD}^{+}$cells were not statistical significance. But the rise in $\mathrm{CD}^{+} / \mathrm{CD}^{+}$ cells ratio $(\mathrm{P}<0.05)$ was found table $-2-$. That is meaning the increasing in activity of immune system in this group of patients. Slight differences in these results were found by some investigators $(14,19)$ and similar results were found by another investigators (23). The increase in $\mathrm{CD}^{+}$ $/ \mathrm{CD}^{+}$cells ratio mean increase in the activity of B- lymphocytes, that is increasing in the concentration of Immunoglobulines (IgG , IgM , \& IgA) table -1- in circulation of patients with AICAH (12). The rise in concentration of IgG \& IgM was found in patients with CHB in spite of low in $\mathrm{CD}^{+} / \mathrm{CD}^{+}$cells ratio that suggests presence of a factor stimulates $\mathrm{B}$ lymphocytes independently on $T$ lymphocytes this factor is $\mathrm{HBc} \mathrm{Ag}(24,12)$. In this study AICAH patients have many markers for infection with HBV . This would suggest that HBV may plays a role in the development of a subgroup of lupoid $\mathrm{CAH}$ as a trigger of autoimmune pathogenic mechanisms (19). In these patients (AICAH) the damage in liver cells is not clearly known, but the recent study suggests that $\mathrm{CD}^{+}$cells and $\mathrm{B}$ lymphocytes which present in the areas of necrosis plays a role in that damage, and thios study may suggest that autoantibodies play a role in this damage (8).

\section{References}

[1] Mills, J. "Viral infections". In: Basic \& clinical immunology. Eds: Stites, D.P.,
Terr, A.I. \& Parslow, T.G., $8^{\text {th }}$ edition. Appleton \& Lang, Medical Book, USA. 1994. pp: 642-5.

[2] Zuckerman, A.J.."Introduction in: progress toward the comprehensive control of hepatitis B", Gut, Vol. 36 1996 (Suppl 2): 1-9.

[3] Edgingto, T.S. and Chisari,F.V., "Immunological aspects of hepatitis B virus infection", Am. J. Med. Sci. Vol. 270 1975, pp: 213.

[4] Marions, G., Francesco, T. and Shilpa, C. "Induction of T-helper cell response to hepatitis B core antigen in chronic hepatitis B. A mator factor in activation the host immune response to the HBV", Hepatol ., Vol. 24, 1995, pp: 1040-9.

[5] Alberti, A., Realdi, G., Bortolotti, F., and Rigoli, A.M. ,T lymphocyte cytotoxcity to HBs Ag coated target cells in hepatitis B Virus infection", Gut , Vol. 18, 1977, pp: 1004 .

[6] Thomas, H.C.,"Cellular immunity to the hepatitis B virus. In: Virus and liver": Bianch, I., Gerok, W., Sickinger, K. and Stalder, G., M.T.P. press limited, Lancaster, 1980, pp:161.

[7] Thomas, H.C., Brown, D., and Labrooy, J.,"T cell subsets in autoimmune and HBV infected chronic liver disease, HBs antigen carriers a review of the abnormalities and effects of treatment", J., Immunol., Vol. 2, 1982,pp: 57-60.

[8] James, S.P., Stroben, W. and Greenspan, J.," Gastrointestinal, Hepatobiliary \& Orodental diseases". In Basic \& Clinical Immunology.Ed: Stites, D.P.,Terr, A.I.\& Parslow, T.G. $8^{\text {th }}$ edition, Appleton \& Lange, USA., 1994, pp:457-477.

[9] Gerber, M.A. and Thung, E.,"The epidemiology of hepatitis B: In hepatitis B", Eds.: Gerety, R.T., Academic press, in C., Florida, 1985,pp:77-92.

[10] Eggink, H.F., Houthoff, H.J., Huitema, S., Gips, C.H. \& Poppema, S., "Cellular and humoral immune reactions chronic liver disease . II. Lymphocyte subsets and viral antigens in liver biopsies of patients with acute and chronic hepatitis B",Clin.Exp.Immunol.,Vol.50, pp:17-24.

[11] Galun, E., Iian , Y., Livni , N.\& Ketzinal,M., "Hepatitis B virus infection 
associated with hepatopoietic tumors", Am.J.Pathol.,Vol.145, 1994, pp: 717-23.

[12] Zgair, K.A., "Some immunological aspects of patients with chronic hepatitis B" , M.Sc. Thesis Baghdad University, College of Science ,pp: 41-44.

[13] Boyum, A. ,"Separation of leucocytes from blood and bone marrow", Scand. J. Clin. Lab. Invest. 21: Supp.Vol.1,pp:97.

[14] Garella, G., Chatenoud, L., Degos, F. \& Bach, M.A.,"Regulatory T-cell subsets imbalance in chronic active hepatitis", J. Clin. Immunol., Vol. 2, 1982,pp: 509-13.

[15] Chu, C.M. and Liaw, Y.F. (1986). Peripheral T-cells subsets in a Symptomatic hepatitis B Virus carriers, Cells Immunol., 98: 533-37.

[16] Jung, M.C., Schraut, W., Santantonio, T., Spengler, U. \& Eichenlaub, D.," Increased frequency of $\mathrm{CD} 8{ }^{+}, \mathrm{CD} 45 \mathrm{Ro}^{+}$ memory $\mathrm{T}$ lymphocytes in acute hepatitis B virus infection", J. Hepatol.,Vol. 18, 1993, pp: 295-300.

[17] Thomas,H.C.,"T cell subsets in patients with acute and chronic HBV infection, primary biliary cirrhosis and alcohol induced liver disease", J. Immunopharmacol., Vol.3, 1981, pp: 301-5.

[18] Chavan, S.S., Amarapukar, D.N. and Kalro, R.H.,"Frequency analysis of proliferating and cytotoxic $\mathrm{T}$ cells in livers and peripheral blood of patients with chronic hepatitis B", J. Med. Microbiol., Vol. 43, 1995, pp: 277-281.

[19] Barnaba, U., Musca, A., Cardova, C., Levrero, M., Ruocco, G., \& Albertini Petrovni, V. ,"Relationship between T cellular subset and suppressor cells activity in chronic hepatitis B virus (HBV) infection", Clin. Exp. Immunol., Vol. 53, 1983, pp: 281-8.

[20] Chu, C.M., Chau, T.Y.and Sheen , I.S., "Subcellular localization of hepatitis core antigen in relation to hepatocyte regeneration in chronic hepatitis B", J. Clin. Fathol., Vol. 48, 1995, pp: 382-7.

[21] Betroletti, A., Costanzo, A., \& Chisori, F.V., "Cytotoxic T-lymphocyte response to wild type hepatitis B virus epitope in patients chronically infected by variant viruses carriage substitation within the epitope", J. Exp. Med., Vol. 198, 1994, pp: 933-43.

[22] Paul,W.E.\& Seder, R.A., "Lymphocyte responses and cytokines",Cell, Vol. 76,1994, pp: 241-51.

[23] Nouri-Aria, K.T., Obo-Yeo, A.I., MieliVergani, G. \& Mowat, A.P.,"T. Suppressor cell function and number in children with liver disease", Clin. Exp. Immunol., Vol. 61, 1985, pp: 283-9.

[24] Gerlich, W. and Thomssen, R., "Terminology structure and laboratory diagnosis of hepatitis viruses. In: Oxford text book of Clinical Hepatology ", Oxford university press, 1991, pp: 543560.

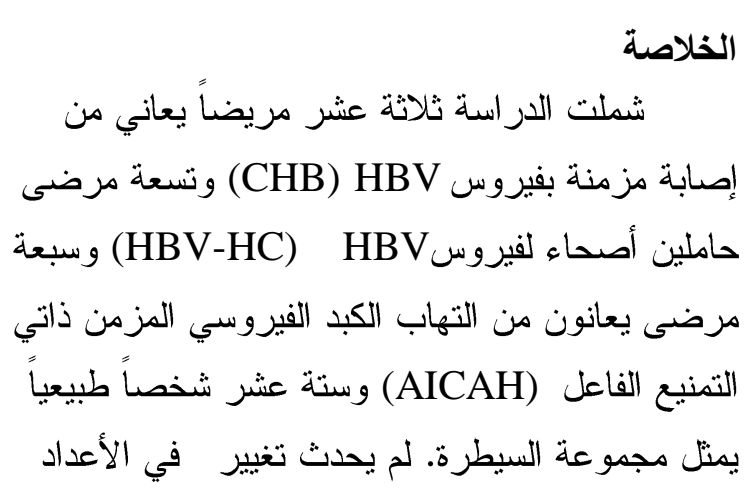

و النسب المئوية للمفاويات النائي : Lymphocytes) (T-CD3 ${ }^{+}$cells المرضى • وجد انخفاض معنوي احصائي (P<0.001) في النسب المئوية واعداد خلايا خلايا مرضى الإصابة المزمنة CHB و التي سجلت ارتفاع معنوي احصائي (P8 ونسبتها المئوية مقارنة مع مجموعة السيطرة. لم يلحظ أي تغير احصائي في النسب المئوية و اعداد خلايا في مجموعة الحاملين الأصحاء CD8 ${ }^{+}, \mathrm{CD}^{+}$ أما في مجموعة مرضى (HBV-HC) وجد زيادة احصائية معنوبية طفيفـة في نسبـة خلابيـا P > 0.05 CD8 $\mathrm{CD}^{+} \backslash \mathrm{CD} 4^{+}$

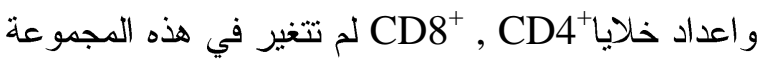
عند مقارنة النتائج مع مجموعة السيطرة. 